\title{
OSMANLI DEVLETI'NDE UYGULANAN İÇKİ YASAĞININ FIKRALARA YANSIMASI
}

\author{
Prof. Dr. Esma ŞiMŞEK ${ }^{*}$ \\ Dr. Ömer Faruk ELALTUNTAŞ**
}

Öz: Halk edebiyatı ürünleri içerisinde yer alan fikralar, halkın değerlerini ve inançlarını yansıtmada etkin role sahiptir. En eski dönemlerden günümüze kadar Türk halkının dünya görüşünü, yaşam felsefesini, zevkini yansıtmakta önemli bir yer tutan fikralar, konuları ve anlatım şekilleriyle halkın mizahi yönünü ortaya çıkarmakta, halkı güldürürken düşündürmektedir. Fıkralar aynı zamanda insan hayatına renk katmakta ve iletişimi zenginleştirmektedir. Fıkralar, yoğun bir anlatım gücüne sahiptir. Bazen saatlerce anlatılacak konuların sadece bir fikrayla özetlendiği görülebilir.

Fıkralar, yaşanan hayattan izler taşımaktadır. Günlük hayatta karşılaşılabilecek olayların hemen hepsini fikralarda görebilmek mümkündür. Diğer konular gibi siyasi ve sosyal konular da fikralar içinde yer almaktadır. Dönemin devlet adamları, bu devlet adamlarının yönetim anlayışları ve halkın bu konulara bakışı/değerlendirmeleri fikralarda rahatlıkla görülmektedir. Bu yönüyle fikralarda insan-toplum-devlet ilişkileri belirgin bir şekilde yer tutmaktadır. Çoğu fikranın konusunu yöneten sınıf ile yönetilen sınıf arasında yaşanan olaylar/çatışmalar oluşturmaktadır. Yöneten-yönetilen ilişkisinde yaşanan ve çoğunlukla yönetilen grubun yanında olup onların sıkıntılarını dile getiren olaylar, her daim insanların ilgisini çekmiştir. Halk; çekindiği, korktuğu ya da dile getiremediği konuları fikra kahramanlarının ağzından söylemektedir. Toplumdaki adaletsizlik, haksızlık, cahillik, baskı, yasak, din istismarı gibi konular, fikralarda eleştirilmekte ve bu yanlışlardan hareketle kıssadan hisse çıkarma hedeflenmektedir.

Bu çalışmada Osmanlı Devleti'nde -özellikle duraklama döneminden itibaren- yoğun şekilde uygulanmaya çalışılan içki yasağının halka yansıması, yasağın uygulanmasında karşılaşılan güçlükler ve uygulanan cezalar, dönemin önemli tiplerine (Bektaşi ve Bekri Mustafa) bağlı olarak anlatılan fikralar ekseninde incelenmeye ve değerlendirilmeye çalışılmıştır.

Anahtar Kelimeler: Osmanlı Devleti, siyaset, fikra, içki yasağı, eleştiri.

THE REFLECTION OF ALCOHOL PROHIBITION WITH ANECDOTES WAS APPLIED İN OTTOMAN STATE

Abstract: Anecdotes in folk literature products has an effective role in reflecting people's values and beliefs. Anecdotes that hold an important place reflecting Turkish people's worldview, life philosophy from old times to day reveal the humorous direction of the people with their forms and narrative forms and make the people think

ORCID ID: *0000-0002-0645-6178 / **0000-0002-8870-4437

DOI : $10.31126 /$ akrajurnal.451022

Geliş tarihi: 08. 07. 2018 / Kabul tarihi: 30. 08. 2018

* Fırat Üniversitesi, İnsani ve Sosyal Bilimler Fakültesi, Türk Dili ve Edebiyatı Bölümü.

** Bingöl Üniversitesi, Rektörlük, Türk Dili Bölümü. 
of it while making them laugh. Anecdotes also add color to human life and enrich communication. Anecdotes have an intense expression. Sometimes it can be seen that the topics to be narrated for hours are only summarized by an anecdote.

Anecdotes are the reflection of life. Within anecdotes, it is possible to see almost all events that may be encountered in everyday life. Political and social issues such as other issues are also included in the anecdotes. Statesmen of the period, the way to govern of these statesmen and public's views on these topics are easily seen in anecdotes. In this respect, human-societystate relations are clearly located in anecdotes. Many anecdote topics include events/conflicts between the ruling class and managed class. The events of governing-governed relationship has attracted the attention of the people at all times. The public speaks about the topics that they can not express or scare, with the lines of the anecdote heroes. Inequities in society, injustice, ignorance, oppression, forbidden and religious abuse are criticized in the subject anecdotes and it is aimed to point a moral from these mistakes.

In this study, the reflections of the alcoholic beverages which are tried to be applied intensively in the Ottoman State, especially after the period of stagnation, the difficulties encountered in the implementation of the law and the punishments applied have been tried to be examined and evaluated on the basis of the anecdotes described as important types of the period (Bektashi and Bekri Mustafa).

Key Words: Ottoman State, politics, anecdote, alcohol prohibition, criticism.

\section{Giriş}

Halk edebiyatı anlatı türleri içerisinde fıkralar önemli bir yere sahiptir. En eski dönemlerden günümüze kadar Türk halkının dünya görüşünü, yaşam felsefesini, zevklerini yansıtmakta önemli bir yer tutan fikralar, konuları ve anlatım şekilleriyle halkın mizahi yönünü ortaya çıkarmakta, dinleyeni güldürmekte ve bunu yaparken de düşündürmektedir. F1kralar, insan hayatına renk katar, iletişimi zenginleştirir. Fıkralarda yoğun bir anlatım söz konusudur. Böylelikle bazen kitaplar dolusu bilginin bir fikrayla özetlenebildiğini görmek mümkündür.

F1kra türünün geçmişi çok eski zamanlara dayanmaktadır. Konuyla ilgilenen bilim insanları farklı farklı tanımlar yapmışlardır. Yazılı kaynaklarda fikrayla ilgili bilgilere ilk olarak Divânü Lügati't-Türk'te rastlamaktayız. Eserde geçen köğ ve külüt sözcükleri bizdeki fikranın karşılığı olarak belirmektedir. Köğ, bir şehir halkı arasında meydana çıkarak bir yıl içerisinde gülünen şey, gülmece, olarak tanımlanır. Külüt ise halk arasında gülünç olan nesne, anlamındadır (Kaşgarlı Mahmûd, 2012: 357).

Ebru Şenocak Ironik Yaşamda Sonsuza Yürüyen Kahraman Nasreddin Hoca adlı eserinde fikrayı: "Sözlü gelenek içerisinde yaşamaya devam eden, mizah anlayışımızı geleneksel formlar içerisinde yaşatan Türk kültür hayatının yoğun anlatımlı türleridir." (Şenocak, 2017: 25) şeklinde tanımlamaktadır. Tanımdan hareketle insanın kendini ve toplumu anlamasında ve olaylara farklı bakış açılarıyla bakabilmesinde fikraların önemli yeri olduğu anlaşılmaktadır. Bazen ifade edilmesi zor olan durumlar dahi bir fikrayla en güzel 
şekilde anlatılır. Bu yönüyle fikralar yeri geldiğinde taşı gediğine oturtma sanatıdır. Fıkralarda tez ve antitez vardır. Olay örgüsü ve diyaloglar önemli bir yer tutar; fakat kilit nokta fikranın sonuç kısmıdır. Fıkranın mizahi ya da eleştirel yönü sonuç kısmında ortaya çıkmaktadır.

Türk Edebiyatında Bektaşi Fıkraları adlı eserinde Dursun Yıldırım fikrayı şöyle tarif etmektedir: "Fıkra, hikâye çekirdeğini hayattan almış, bir vaka veya tam bir fikrin teşkil ettiği kısa ve yoğun anlatımlı, beşeri kusurlarla içtimai ve gündelik hayatta ortaya çıkan kötü ve gülünç hadiseleri, çarpıklıkları, zıddiyetleri, eski ve yeni arasındaki çatışmaları, sağduyuya dayalı ince bir mizah, hikmetli bir söz, kekin bir istihza yolu ile yansitan; umumiyetle bir fikra tipine bağlı olarak nesir dili ile yaratılmış, sözlü edebiyatın müstakil şekillerinden ibaret yaygın epik-dram türündeki realist hikâyelerden her birine verilen isimdir." (Y1ldırım, 1999: 3).

Yukarıdaki tanım, bu tür ile ilgili en detaylı tanımlardan biridir. Bununla birlikte fikraların ortaya çıkış ve anlatılış gerekçeleri üzerine Pertev Naili Boratav şöyle demektedir: "Güldürücü fikralar ve nükteli küçük hikâyeler fikra, latife, nükte ve birçok hâllerde de sadece hikâye deyimleri ile gösterilirler. Bunlarda tıpkı hayvan masallarında olduğu gibi kısa hatta onlardan daha yoğun bir anlatı tekniği uygulanmıştır. Sirası düşünce herhangi bir düşünceyi örnek vererek güçlendirmek, karşısındakini ona inandırmak ya da direnişinde yanıldı̆̆ına tanık göstermek, herhangi bir durumu açıklamak gibi verilerle anlatılır bu hikâyeler." (Boratav, 200a: 91-92).

Bunların dışında biz de, daha önceki bir çalışmamızda fikrayı şöyle tanımlamıştık: "Fıkra, genellikle konusunu yaşanılan hayattan alan; temelinde hiciv, alay ve mizahın birlikte yer aldiğg, herhangi bir olayı açıklamak, eleştirmek, birilerine ders vermek ya da imada bulunmak amactyla anlatılan kısa ve yoğun anlatım gücüne sahip mensur metinlerdir." (Şimşek, 2015: 198). Bütün bu açıklamaların 1şı̆̆ında denilebilir ki; fikralar, gerçek hayatın etkisiyle oluşmuş, vaka örgüsünde zıtlıklar barındıran, çeşitli durumları izah etmek ya da örneklendirmek üzere anlatılan, güldüren, ders veren ya da eleştiren, kısa ve nükteli bir anlatıma sahip halk anlatılarıdır. Toplum psikolojisini, uzun bir zaman diliminde oluşmuş hayat görüşünü, denenmiş ve gözlenmiş gerçekleri yansıtan fikralar, ifade edilmesi ya da anlaşılması zor duygu ve düşüncelerin daha kolay bir biçimde ifade edilmesine ve anlaşılmasına yardımcı olan anlatılardır. Özlü ve etkili bir dille anlatılan bu metinler, diyaloğu rahatlatmak, dinleyicinin tepkisini çekmek ve söze etkileyici bir giriş yapmak, konuşmanın sonunda akılda kalıcı ve daha etkili olması için son sözü söylemek maksadı ile anlatılabilirler. Konuşma içinde geçen herhangi bir durumla ilgili olarak daha açıklayıcı olmak maksadıyla örnek gösterilebilirler. Toplumun inançlarını, âdet ve merasimlerini, fikir mücadelelerini, geleneklerini, dünya 
görüşünü yansıtan fikralar, yaratıldıkları zamanda bünyelerinde barındırdıkları kültürel bilgileri ve deneyimleri geleceğe aktarırlar. Böylece geçmiş kuşaklarla gelecek kuşaklar arasında bir bağ kurarlar. Charles Seeger'in tüm kültür ürünleri için kullandığı tabiriyle "zaman birleştirici" (Ferris, 1997: 87) bir rol oynayarak birey ile kültürü arasındaki bağları güçlendirirler. Fıkraların bir toplumun kültürüne dair bilgileri bünyesinde barındırması ve bunu gelecek kuşaklara aktarması onların birer sözlü tarih materyali olarak görev yapmasını sağlamaktadır.

Fıkralar, konularını birey-toplum ilişkisindeki çelişkilerden ya da farklılıklardan almaktadır. Bu yönüyle bakıldığında hayata ve insana dair her şey fikralara konu olabilmektedir. Bu konulardan biri de hiç şüphesiz, siyasettir. Siyasi olaylar ya da siyaset adamları her zaman, her yönüyle fikralara konu olmuşlardır. Devletlerin yönetim biçimlerinin, yöneticilerinin, yöneten-yönetilen ilişkilerinin ve yönetimdeki aksaklıkların irdelendiği, çoğu zaman mübalağa ve eleştiri içeren ve ilk söyleyenleri belli olmayan fikralar, siyasi fikra olarak adlandırılmaktadır. Bu tür metinler, fikra örnekleri içerisinde en yoğun olanlarıdır. Siyasi fikralar, zengin halk kültürümüzün dinamizmi sayesinde sürekli yenilenmekte ve her geçen gün yeni ürünler sayesinde genişlemektedir. Bir eleştiri türü olan siyasi fikralarda yaklaşımlar acımasızca olabilmektedir. Halk, normal şartlarda söylemeye cesaret edemediğini fikralar sayesinde yöneticilerine ulaştırabilmektedir. Siyasi ve sosyal anlamda sorunların arttığı dönemlerde siyasi fikraların niteliği ve niceliği de artmaktadır. Sadece Türk kültüründe değil, bütün dünyada siyasi fikralar mevcuttur. Bu fikraların genelinde olumsuz bir siyasetçi imajı çizilmektedir. Fıkralara göre siyasetçi çok ve boş konuşur, s1k sık yalan söyler, yerine getiremeyeceği vaatlerde bulunur. İktidara ulaştıktan sonra ise vaatlerini unutur, kendi çıkarını halkın ve devletin çıarlarından üstün tutar. Halkın tasavvurunda yüzyılların birikimi neticesinde siyasetçilerin imajı bu hâli almıştır. Siyasi fikralar sayesinde bu durumlar anlatılmış, devlet yönetimindeki aksaklıklar gözler önüne serilmiştir. Yasaklar, rüşvet, adam kayırma, adaletsizlik, dalkavukluk ve bunlara benzer konular tenkit edilmiştir. Siyasi fikralara bağlı olarak tenkit edilen önemli konulardan biri de içki yasağ 1 ve bu yasağa yönelik eleştirilerdir. Bu konuyu iki başlık altında değerlendirmeyi uygun bulduk:

\section{Padişah İradesiyle Uygulanan Yasağın Fıkralara Yansıması}

Siyasi fikralarda, üzerinde durulan önemli konulardan biri içki yasağı ve bu yasağın uygulanma şekilleridir. Özellikle Bektaşi ve Bekri Mustafa fikralarında, Osmanlı döneminde uygulanan içki yasağı sıklıkla eleştirilmiştir. Bilindiği üzere içki, İslamiyet’te kesin hükümlerle haram kılınmıştır. Türkler 
de İslamiyet'in kabulüyle birlikte İslami inanışla ters düşen gelenek ve alışkanlıklarını terk etmeye çalışmışlardır. Halk arasında durum böyleyken Türk devletleri de içki içilmesini kanunlarla ya da fermanlarla yasaklamıştır. İslamiyet'i kabul eden ilk Türk devleti olan Karahanlılar zamanında Yusuf Has Hacib tarafindan kaleme alınan Kutadgu Bilig'de dâhi içki yasağından ve bunun hükümdar eliyle takip edilmesinden bahsedilmektedir (Yusuf Has Hacib, 2003: 157-158). Zaman içerisinde bu yasak, diğer Türk devletlerinin hukuk kuralları içinde de yer almış ve Osmanlıya kadar uzanmıştır. Osmanlı Devleti'nde de kuruluş aşamasından itibaren başta içki olmak üzere sarhoşluk veren tüm içecekler kesin hükümlerle yasaklanmıştır. Bununla birlikte yasağa uymayanların İslami usullere uygun şekilde cezalandırılacakları açıkça belirtilmiştir. Yasağın uygulanmasında kimi padişahlar daha titiz, kimi daha esnek davranmıştır. İslam hukukuna göre içki içenlere 80 sopa cezası anlamına gelen hadd-i şirb cezası uygulanmıştır. Osmanlı padişahları içerisinde ilk olarak Sultan II. Bayezid'in ferman yayınlayarak içki yasağını uygulamaya koyduğu bilinmektedir. Devamında Kanuni Sultan Süleyman, I. Ahmet, III. Selim ve II. Mahmud içki yasağını katı şekilde uygulamaya çalışmışlar; fakat buna rağmen meyhanelerin sayısı azalmamış ve içki içenler kendileri için uygun şartları bulmaya devam etmişlerdir. İçki yasağının en katı şekilde uygulanması IV. Murad döneminde olmuştur. Fakat bu dönemde dahi gayrimüslim halkın yaşadığı Galata gibi yerlerde, bazı Müslümanların da kaçamak yaptığı meyhaneler bulunmaktadır. Bektaşiler de bu grubun içerisinde yer almışlardır. İçki yasağına bağlı anlatılan Bektaşi fikralarında bu durum eleştirilerek zor şartlar altında içki içen, çoğu zaman yakalanan ve durumu mizahi bir hâle getirerek sıyrılmayı başaran Bektaşiler anlatılmaktadır:

"Karaağaçtaki Bektaşi tekkesi dervişlerinden birkaçı, nevalelerini alarak Kâğthane'ye gidip köprüye yakın bir yere yerleşir, işrete başlarlar. Tam cümbüsslendikleri sırada Ü̧̧üncü Selim 'in saltanat kayığı, pek yakindan görünmesiyle ne yapacaklarını şaşırırlar ve içlerinden birinin ihtarı üzerine acele kalkı birden namaza dururlar. Fakat işret takımını kaldırıp saklamağa vakit bulamadıklarından sürahiler, kadehler, meze takımları meydanda kalır.

Padişah, aheste giden kaylkta bunları seyre başlar. Bunlar da hiç klyamı bozmazlar. Padişah bir müddet temaşadan sonra gülerek:

- Bu ne acayip namaz; hiç rükûu, sücudu yok, çekinmesinler, zevklerinde olsunlar, diye kendilerine haber ve ihsan gönderir." (Yıldırım, 1999: 126).

Osmanlı padişahları içerisinde içki yasağını en çok destekleyenlerden biri olan, şiiri ve müziği çok sevmesine rağmen döneminde tüm meyhaneleri kapattıran III. Selim' in bu fikrada Bektaşilerin hâline tebessüm etmesi ve sarhoş hâlde namaza durarak komik hâle düşen Bektaşilere acıyarak eğlencelerine devam etmelerini söylemesi oldukça ilginç bir durumdur. Sultan II. Mahmud dönemine bağlı olarak anlatılan bir başka fikra örneği de şöyledir: 
"II. Sultan Mahmud devrinde bir Ramazan günü zaptiyeler bir Bektaşi babasını rakı içerken suçüstü yakalar. Padişaha götürürler. Bektaşi rakı şişesini saklayarak huzura çıkar. İkinci Mahmud:

- Erenler, elini göster, der.

Bektaşi sol elini gösterir. Ötekiyle şişeyi saklar.

- Öteki elini de göster.

Baba arka arkaya yürüyerek duvara gelip dayanır. Şişeyi duvarla sırtı arasında sikıştırarak iki elini birden gösterir.

Ikinci Mahmud bu sefer şu emri verir:

- Şimdi öne doğru gel.

Bektaşi dayanamayarak:

- Halt etme Mahmud, bana şişeyi kırdıracaksın, der." (Yıldırım, 1999: 171172).

Sultan II. Mahmud'a bağlı olarak anlatılan bu fikranın da mizahi yönü oldukça fazladır. Osmanlı idaresinde içki içen her kişi padişahın huzuruna çıkarılacak olsa, padişahın tüm devlet meselelerini bir kenara bırakıp bu konuyla ilgilenmesi gerekirdi. Ayrıca Bektaşi'nin, padişahın huzurundayken kendisiyle bu şekilde nezaket dışı konuşabilmesi de ihtimal dâhilinde değildir. $\mathrm{Bu}$ yönleriyle baktığımızda yukarıdaki fıkranın tarihî gerçeklik payı yoktur; fakat mizahi yönden oldukça nüktelidir. Öte yandan padişahların içki içmediğine dair birçok tarihî kayıt vardır; fakat Sultan II. Mahmud'un içki içtiğini söyleyen Osmanlı tarihçileri de mevcuttur. Ayrıca diğer birçok padişah içki yasağını sert bir şekilde uygulatırken Sultan II. Mahmud, bu yasağı daha yumuşak bir şekilde uygulatmıştır. Padişahın içkiyle alakalı Bektaşi'yi tahkikata aldığını anlatan bir başka fikra ise şöyledir:

"İstanbul'un meşhur ayaklanmalarının birinde padişah sarayının etrafinı saran halkın 'istemezük, istemezük' diye bağırmalarına hiçbir şeyden habersiz içkili Bektaşi de katılır, o da 'istemezük' diye bağırmağa başlar. Neyi istemediklerini anlamak maksadıyla halkın arasına katılan padişah soruşturma neticesinde sadrazamı istemediklerini anlar.

Bu arada padişah Bektaşi'yi de sorguya çeker. Hiçbir şeyden haberi olmayan baba erenler:

- Ben meyhaneci Anastas'ı birkaç günden beri şaraba fazla su kattı̆̆ için istemiyorum, deyince bu cevaptan hoşlanan padişahın ihsanına nâil olur." (Yıldırım, 1999: 174).

Bektaşi fikralarının en önemli özelliği yaşandığı dönemi, yani Osmanlı Devleti'nin gerileme ve yıkılma dönemini, kendi mizahi üslubuyla yansıtmasıdır. Yukarıdaki fıkrada Osmanlı Devleti'nin son dönemlerinde sıkça vuku bulan İstanbul isyanlarından bahsedilmektedir. Asayişin sağlanmasında zorlukların yaşandığı, devlet otoritesinin eskisi gibi güçlü olmadığı bu dönemde sık sık isyanlar çıkmış ve bu isyanlar önceden olduğu gibi kolaylıkla bastırı- 
lamamıştır. Osmanlının son dönemlerinde yöneticiler de eskisi gibi liyakat sahibi olmadığından halk, beğenmediği yöneticiler için rahatlıkla isyan etme cüretinde bulunmuştur. $\mathrm{Bu}$ yüzden onlarca devlet adamı sorgusuz sualsiz katledilmiş ya da görevinden azledilmiştir. Öte yandan fikranın devamında isyandan haberi olmayan Bektaşi'nin meyhaneci Anastas'tan şikâyetçi olması da İstanbul'un o dönemdeki sosyal hayatından kesitler sunmaktadır.

Osmanlı Devleti'nin payitahtı İstanbul' da eğlence sektörü her daim var olmuştur. Yasağın uygulandığı dönemlerde bu durum sekteye uğrasa da mütemadiyen devam etmiştir. İstanbul'da meyhaneler Müslüman mahallelerinde açılmamıştır. Müslümanların meyhane açmaları ve işletmeleri yasaktır. Gayrimüslimlerin açtıkları bu meyhaneler, onların yaşadığı mahallelerde bulunmaktadir.

Tarihin eski dönemlerinden günümüze kadar eğlence mekânı olarak kullanılan meyhane, Osmanlılar döneminde aynı zamanda şair mahfillerinden biridir. O dönemlerde meyhanelerin çoğu, İstanbul'un Tahtakale, Balıkpazarı, Galata gibi semtlerinde toplanmıştır. Yaz dönemlerinde ise deniz kenarlarında açık meyhaneler de kurulur. Tahtakale, İstanbul halkı için ideal bir eğlence semtidir. Sarhoş ve esrarkeşler buraya toplanır, cambaz ve hokkabazlar burada gösterilerde bulunurlar. Efe ve Yani Meyhaneleri, Tahtakale'nin en meşhur meyhaneleri olarak bilinir. Galata ise daha çok gayrimüslimlerin ikamet ettiği yer olduğu için eğlenme konusunda diğer semtlere göre daha serbesttir (İpekten, 1996:244-245).

Yukarıdaki fikrada da Bektaşi'nin zikrettiği meyhaneci Anastas'ın ismi, Müslümanlar tarafindan kullanılan bir isim değildir. Dolayısıyla bu fikra, dönemin İstanbul'unun eğlence ve meyhane kültürü hakkında bilgi vermektedir. F1krada Bektaşi, kendi durumundan ötürü padişahın karşısında oldukça güç ve komik bir duruma düşmüştür. Bu fikranın benzer bir örneği de şöyledir:

"Bektaşilerden biri, içkinin yasak olduğu devirde, bir şişe şarap almış. Cübbesinin altına saklamış giderken padişah rast gelmiş. Padişah:

- Nedir o cübbenin altındaki?' diye sormuş. Bektaşi de:

- Abdest suyu sultanim, demiş. Padişah:

- Çıkar bakalım, şarap olmasın, deyince Bektaşi:

- Padişah hürmetine şarap ol yâ mübarek, diyerek şişeyi çıkarır.

Padişah bakar ki şarap.

- Şimdi de su yap bakalım, der. Bektaşi:

- Ben bu kadarını yaptım. Nüfûz-ı padişahî büyüktür. Ötesini de siz yapınız sultanım, der." (Yildırım, 1999: 174).

Önceki fikralarda olduğu gibi yukarıdaki fikrada da içki yasağına uymayan Bektaşi'nin zor duruma düştüğü görülmektedir. Bektaşi yakalanma- 
ması gereken kişiye, yasağı koyana, yani padişaha yakalanmıştır. Yasağı delen Bektaşi, suçlu bir hâlde padişahın huzurunda durmaktadır. Eğer yakalanan ve padişahın huzurunda olan kişi bir Bektaşi olmasa, muhtemelen ciddi bir cezaya çarptırılır; fakat Bektaşi'nin kıvrak zekâsıyla verdiği cevaplar, durumu tersine çevirerek onun canını kurtarmıştır. Bu fikrada dikkat edilmesi gereken bir başka husus da, Bektaşi'nin sözde suyu şaraba çevirdikten sonra, şarabın tekrar suya çevrilmesi işlemini kendisinin yapamayacağını ve buna ancak padişahın gücünün yetebileceğini vurgulamasıdır. Burada Bektaşi, kut anlayışına değinmiştir. Bu çalışmada daha önce de bahsedildiği gibi Türk tarihinin her döneminde hükümdara yönetme gücünün Tanrı tarafından verildiğine inanılmaktadır. Bu anlayışta Türk hükümdarları Tanrı tarafından seçilmiş kudretli kişilerdir. Böyle olunca, Türk hükümdarı, kimsenin çözemediği sorunları çözen, kimsenin yenemediği düşmanı yenen, kimsenin başaramadığ 1 işleri başaran kişidir. Nitekim Ricaut'un da dediği gibi: "Padişahın sınırsız imparatorluğunun en önemli dayanağıdır.” (Ricaut, 2004: 10). F1krada Bektaşi’nin bahsettiği şekliyle kendisi ancak suyu şaraba çevirebilmiştir. Gücü daha fazlasına yetmemiştir. Buna gücü yeten ise iktidarının gücünü Tanrı'dan alan Türk hükümdarıdır.

Bektaşi'nin içki yasağının olduğu dönemde padişahla karşılaşmasını ve içine düştüğü durumu anlatan bir başka fikra da şöyledir:

"İçkinin şiddetle memnu olduğu bir zamanda, gizli meyhanelerden birinde demlenen Bektaşi, salına salına giderken birden bire aşina bir çehre ile karşılaşmış. Hemen teklifsizce elini o çehre sahibinin omuzuna koyarak, sormağa başlamış.

- Imanım, seni iyice gözüm ısırıyor. Acaba nerede gördüm, Fenerdeki Çardaklı meyhanede mi?

- Hayir.

- Öyleyse, Tavukpazarı'ndaki Küplü'de.

- Hayir.

- Eh, o hâlde, mutlaka Uzunodalar'da.

- Hayır.

- Allah Allah... Bâri söyle de meraktan kurtulayım.

- Herhâlde sen beni selamlık ettiğin zaman görmüss olacaksın.

Bektaşi karşısındaki adamın padişah olduğunu anlamış. Artık söyleyecek söz bulamamış. Hemen oraya sırtüstü yatarak:

- Ey ahali... Ben kalıbı değiştiriyorum, buyurun cenaze namazına, diye bağırmıs." (Yıldırım, 1999: 127-128).

Yukarıdaki fikrada da içki yasağını çiğnediğini alenen belli eden Bektaşi'nin, bu durumu en son anlatması gereken insana, yani padişaha anlattığı görülmektedir. Bektaşi aldığı cevapla karşısındakinin padişah olduğunu anlayınca da durumu dramatik bir hâle getirmiştir. Bektaşi'nin zikrettiği yer isimleri gizli meyhanelerin bulunduğu yerlerdir. Padişahın da bu yerleri bilmeme 
ihtimali yoktur. Sultan IV. Murad gibi bazı padişahların bu gizli mekânlara tebdili kıyafetle gidip kimin ne yaptığını yerinde görmeleri ve içki içenleri cezalandırmaları sık karşılaşılmış bir durumdur. Bu fikrada padişahın ismi zikredilmemiştir; fakat padişahlardan birinin tebdili kıyafetle denetim yaptığ1 anlaşılmaktadır. Yine fikrada dikkat edilmesi gereken bir diğer husus, padişahın Bektaşi'ye kendisini selamlıkta görmüş olabileceğini söylemesidir. Selamlık, Osmanlı padişahlarının cuma namazına gidiş ve dönüşleri sırasında yapılan törendir. Osmanlı Devleti'nde cuma namazı dinî açıdan olduğu gibi sosyal açıdan da önemli bir yere sahiptir. Padişahlar, at üstünde ve bir törenle büyük camilerden birine giderek cuma namazlarını kılmışlardır. Özellikle Yavuz Sultan Selim Han döneminde halifeliğin Osmanlıya geçmesiyle bu konuya daha çok önem verilmiştir. Cuma namazının ve cuma hutbesinin eda edildiği camilerin tüm Müslümanlara açık olması, padişahın halkla yakından görüşmesine olanak vererek halkın sorunlarını ve isteklerini ona açıklamalarını sağlamıştır. Namazdan sonra padişahın önünde resmigeçitler düzenlenmiş, halk da bu törenlere büyük bir ilgiyle icabet etmiştir. Selamlığın hangi camide yapılacağı önceden bilinmediği için halk sarayın önünde bekler ve padişah çıkınca onunla birlikte hareket eder. Halkın arasında alkışçı diye tabir edilen kişiler de bulunmaktadır. Bunlar padişaha dua eden, onu öven, ona ölümü hatırlatan, gurur ve kibre kapılmamasını tembihleyen kişilerdir.

Bektaşi fikralarında olduğu gibi Bekri Mustafa fikralarında da içki yasağı konusu gündeme getirilmektedir. Hatta Bekri Mustafa fikralarının tamamına yakınının konusu içki yasağıdır. Bekri Mustafa'nın IV. Murad'ı içkiye alıştırmasına bağlı olarak anlatılan bir fikra şöyledir:

"IV. Murad şarap içilmesini yasakladĭ̆ sıralarda bir gece gezerken Bekri Mustafa'ya rastlar. Bekri Mustafa sarhoştur ve şöyle demektedir:

- Ben dilersem bütün İstanbul'u ve 'cariyeoğlu'nu satın alırım.

Bu sözüyle bir cariyeden doğma olan padişahı kastetmektedir. IV. Murad, onu yakalatır; aklı başında olmadığı için Bekri'yle konuşup anlaşmak mümkün değildir. Padişah da merak eder ve Bekri'yi idam ettirmez; saraya gönderir. Ertesi sabah padişah, Bekri Mustafa'yı huzuruna çağırtır. Geceki sözlerini hatırlatır. Bekri Mustafa koynundan bir şişe çıkarır:

- Bu öyle bir altın sudur ki dünyanın bütün hazinelerine üstündür. Bir dilenciyi cihangir; kudretsiz bir adamı İskender yapar, der ve bu sözlerin doğruluğuna yemin eder.

Sultan Murad Bekri'nin bu şen ve korkusuz sözlerine şaşııır, ondan hoşlanır, şişeyi alarak boşaltır, beğenir. O günden sonra Bekri Mustafa, padişahın birinci derecede işret arkadaşları arasına katılır.

İstanbul'da taun salgını olduğu ve günde yüzlerce insanın öldüğ̈̈ sırada IV. Murad: 
- Allah bu yaz kötülerin cezasını veriyor; bu kış da sıra iyilere gelecektir! diyerek Beyoğlu'nda bulunabilen en büyük kadehleri boşaltmakla meşguldür." (Kaflı, 1943: 52-53).

- F1kralardan anlaşıldığı kadarıyla, Bekri Mustafa İstanbul'da yaşamış, Sultan IV. Murad'ın nedimliğini yapmıştır. Kimi zaman Sultan IV. Murad tarafından özel olarak görevlendirilerek Sivas, Bağdat ve Bursa'ya gönderilmiştir. Bekri Mustafa, yönetimsel sorunların, kaos ortamının ve isyanların yoğun olduğu bir dönemde yaşamıştır. Yaşadığı döneme bağlı olarak anlatılan fikralarda, onun yasaklarla ve baskılarla mücadele ettiği anlaşılmaktadır. Bu yasakların en önemlisi içki yasağıdır ki Bekri Mustafa ile ilgili fikralarda bu konu geniş bir yer tutmaktadır. Bekri Mustafa, içki yasağını her firsatta delmiş ve sarhoşluğuyla meşhur olmuştur.

Bekri Mustafa, içki yasağının katı bir şekilde uygulandığı ve bu yasağa uymayanların cezalandırıldığı IV. Murad zamanında yaşamıştır. O, yaşadığı dönemde halkın sesi/temsilcisi olmuştur. Yaşadığ dönemin en önemli yasağ olan içki yasağına hiç aldırış etmemiş, gece gündüz demeden sarhoş dolaşmıştır. Yasakların ve yasağı çiğneyenlerin cezalandırılmalarının bu kadar yoğun olduğu bir dönemde bu yasağı her seferinde delmesi, Bekri Mustafa fikralar1nın özünü oluşturmaktadır.

Onun, içki yasağından dolayı IV. Murad ile karşı karşıya gelmesi üze30 rine anlatılan bir başka fikra ise şöyledir:

“Bekri Mustafa, Üsküdar İskelesi’nde kayıkçılık yaparken, bir gün Sultan Murad ile Sadrazam Bayram Paşa tebdil gelirler ve mahsus koca ayyaşın kayığına binerler. Sahilden bir hayli açılınca, kayıkçı rakı testisini dikip birkaç yudum içer. Sultan Murad:

- Baba destiyi uzat, bir yudum da ben içeyim! der. Mustafa güler:

- Sen içemezsin oğul, içindeki su değil, rakl! der. Padişah:

- Niye içmeyelim? Deyince

- Tahammül edemezsin, belli mi olur, hem kendinizi hem beni yakarsinız! der. Beriki usrar edince destiyi uzatır. Yol aladursunlar, desti elden ele dolaşır. Bir ara Sultan Murad:

- Baba, sen Padişah yasağından korkmaz misın? diye sorar. Bekri Mustafa:

- Korkarım, amma Padişah beni burada nerden görecek? der. Padişah:

- Ya ben haber verirsem? deyince:

- Veremezsin, sen de içtin, kellelerimiz beraber düsser! cevabını verir. Bunun üzerine çakır keyif olan hükümdar:

- Ya ben padişah, bu adam da Sadrazam Bayram Paşa ise! deyince, Bekri Mustafa kürekleri bırakıp kahkahayı atar:

- Seni köftehor! Ben demedim mi tahammül edemezsin diye! Şunun şurasinda iki yudum rakı içtiniz, biriniz padişah, biriniz vezir olmaya kalktınız!’' (Seratl1, 2004: 212). 
Yukarıdaki fikrada Sultan IV. Murad ve Sadrazam Bayram Paşa'nın, Bekri Mustafa'nın kayığına binerek boğazda yaptıkları gezinti anlatılmaktadır. Kayıkçılık, henüz köprülerin yapılmadığı dönemde, her kesimden insanın Asya ile Avrupa arasında geçişlerini sağlamak ya da sadece gezinti yapmak maksadıyla kullandıkları en önemli ulaşım yöntemi olmuştur. Dönemin İstanbul'unda çeşitli iskeleler ve bu iskelelerde çalışan birçok kayık bulunmaktadır. Bu kayıklar içerisinde en ihtişamlısı, en hızlısı ve en sağlamı sultan kay1ğıdır (Orhonlu, 1966: 109-112). Sultan IV. Murad ve sadrazamı, tebdili kıyafet gelerek sultan kayığını kullanmamışlar; özellikle Bekri Mustafa'nın kayığına binmişlerdir. Diğer bazı fikralarda geçtiği gibi bu fikradan hareketle Sultan IV. Murad'ın Bekri Mustafa'yı tanıdığı anlaşılmaktadır. Sultan'ın Bekri Mustafa'nın kayığına binmesi ve Bekri'nin içtiği rakıdan içmesi Sultan Murad'ın, Bekri Mustafa ile birlikte içki sohbetleri yaptığı fikrini akla getirmektedir; fakat gerçekte durum böyle değildir. "Osmanlı padiş̧ahları, aileleri dâhil, hiç kimseyle beraber yemek yemezlerdi. Hatta buna dair Fatih Kanunnamesi'nde hüküm bile vardır. Sultan Abdülhamid'in son senesine kadar da bu gelenek devam etti. Öyleyse padişahlart içki içerken kimsenin görmesi mümkün değildir. Mamafih içmiş olabilirler. Peygamberler dışında hiç kimse masum saylmaz. Herkes hata yapabilir, günah işleyebilir. Ama görmeden ve iyice bilmeden bir kimse hakkında hüküm de verilemez. Amansız içki ve tütün yasağtyla meşhur Sultan IV. Murad da içki içmediği hâlde, müptela olduğu gut hastalı̆̆ının ăgrılarını hafifletebilmek için hekimbaşı tarafindan verilen afyon hülâsalarını (morfin) alırdı. Bu da kendisinde halsizlik ve uyuşukluk yapardl. Sendeleyerek yürüdügünü birkaç defa görenler padişahın içki içtiğine hükmetmekten çekinmemiştir. Babası gibi Üsküdarl Aziz Mahmud Hüdai'ye bağlıydı. Selden yıkılmış olan Kâbe-i Muazzama'nın bugünkü binasını yaptırmiş; Karaköy Arap Câmiini harap bir bina iken şimdiki hâle getirmiştir." (Ekinci, 2014: 199).

Sultan IV. Murad'ın içki içmediği kesin olarak bilinmemektedir. Bu durumun günümüz şartlarında tartışılmasının pek bir önemi de yoktur; fakat gerçek olan şudur ki, içki yasağını çok şiddetli bir şekilde uygulamıştır. Öbür yandan fikralardan anlaşıldığı kadarıyla Bekri Mustafa, nükteli ve hazırcevap hâli sayesinde her seferinde padişahın yüzünü güldürmüş, şiddetle uygulanan bu yasaktan ceza almayıp her seferinde kurtulmayı başarmıştır. Bu durumun bir örneği de aşağıdaki fikrada görülmektedir:

"Sultan Murad tebdili kiyafet dolaşırken Bekri Mustafa'nın demlendiği yere geldi. O da oturup sohbete ve onlarla beraber içmeye başladl. Bekri bir ara yeni gelene sordu:

- Hoş geldin Ağa, adını bağışlar mısin?

- Hoş bulduk! Adım Murad, ya senin adın ne? 
- Bana adiyla saniyla Bekri Mustafa derler! Sana kim derler?

- Bana da Sultan Murad derler! deyince Bekri'nin ağzından gayri ihtiyari şu sözler döküldü:

- Buyurun cenaze namazına!

- Padişah bu samimi davranış ve nükteli sözler üzerine gülmeye başlayıp Bekri'yi affetti." (Seratl1, 2004: 197).

Bu fikranın bir benzeri Bektaşi tipine bağlı olarak da anlatılmaktadır. Yine tebdili kıyafet gelen padişah, Bektaşi ile birlikte içki içmiş; tanışmaları neticesinde karşısındakinin padişah olduğunu anlayan Bektaşi benzer şekilde yanıt vermiştir. Bu fikrada da dönemin İstanbul'unda içki yasağından ötürü insanların gizli saklı yerlerde içki içtiği, yasağı deldiği ve padişahın tebdili kıyafet gezerek denetimler yaptığ 1 görülmektedir.

\section{II. İçki - Ceza İlişkisinin Fıkralara Yansıması}

İslam dininde, alkollü içki tüketimi kesin olarak yasaklanmış ve diğer yasaklarda olduğu gibi bu yasağa da uymayanlara çeşitli cezai yaptırımlar uygulanmıştır. Osmanlı Devleti'nin hukuk sisteminin temelini de İslamiyet'in şeri hukuku oluşturmaktadır.

İslam hukukunda suçlar çeşitlilik göstermektedir. Kullara karşı işlenen suçlar olduğu gibi Allah'a karşı işlenen suçlar da vardır. İçki ise, Allah'a karşı işlenen suçlardandır. İslam hukukunda bazı suçlar için Kuran'da belirtilmiş, değişmez cezalara hadd denmektedir. Hadd cezasının ağır yaptırımları olduğu için söz konusu suçların hâkim önünde ispatlanması çok güç şartlara bağlanmıştır. Diğer suçlarda şikâyetçinin, devlet başkanının veya hâkimin affetme yetkisi varken hadd cezası gerektiren suçlarda affetme ya da şikâyet etme zorunluluğu söz konu değildir. İçki içmek, Kuran'da yasaklanmış olduğu hâlde işlenen suç için konulmuş bir ceza yoktur. İçki içme cezası hadd-i şürb ya da hadd-i sekr olarak adlandırılmaktadır. Bu suçun cezası daha sonra icma ile kabul edilmiş ve özgür insanlar için seksen, köleler için kırk değnek olarak belirlenmiştir. Cezanın uygulanması ya da uygulanmaması için çeşitli şartların oluşması gerekmektedir. Suçun sabit olduğunun tanıklar tarafından ifade edilmesi, kişinin kendi rızasıyla içmesi ve kişinin Müslüman olması bu şartlardan bazılarıdır (Akbulut, 2003: 167-181).

Görüldüğü gibi içki, Müslümanlara haram kılınmış ve Osmanlı hukukunda içki içmenin karşılığı olarak bazı cezalar belirlenmiştir. Fıkralarda da fikra kahramanlarının sıklıkla içki içerken yakalandıkları görülmektedir. Fakat çoğu kez yakalanan kişiler bir yolunu bulup cezadan kurtulmaktadır. Örneğin Bekri Mustafa:

“- Bana da Sultan Murad derler! deyince Bekri’nin ăgzından gayri ihtiyari şu sözler döküldü:

- Buyurun cenaze namazına! 
Padişah bu samimi davranış ve nükteli sözler üzerine gülmeye başlayıp Bekri'yi affetti." (Seratl, 2004: 197).

Bu fikranın bir benzeri Bektaşi tipine bağlı olarak da anlatılmaktadır. Yine tebdili kıyafet gelen padişah, Bektaşi ile birlikte içki içmiş; tanışmaları neticesinde karşısındakinin padişah olduğunu anlayan Bektaşi benzer şekilde yanıt vermiştir. Bu fikrada da dönemin İstanbul'unda içki yasağından ötürü insanların gizli saklı yerlerde içki içtiği, yasağı deldiği ve padişahın tebdili kıyafet gezerek denetimler yaptığı görülmektedir.

\section{II. İçki - Ceza İlişkisinin Fıkralara Yansıması}

İslam dininde, alkollü içki tüketimi kesin olarak yasaklanmış ve diğer yasaklarda olduğu gibi bu yasağa da uymayanlara çeşitli cezaî yaptırımlar uygulanmıştır. Osmanlı Devleti'nin hukuk sisteminin temelini de İslamiyet'in şer'i hukuku oluşturmaktadır.

İslam hukukunda suçlar çeşitlilik göstermektedir. Kullara karşı işlenen suçlar olduğu gibi Allah'a karşı işlenen suçlar da vardır. İçki ise, Allah’a karşı işlenen suçlardandır. İslam hukukunda bazı suçlar için Kuran'da belirtilmiş, değişmez cezalara hadd denmektedir. Hadd cezasının ağır yaptırımları olduğu için söz konusu suçların hâkim önünde ispatlanması çok güç şartlara bağlanmıştır. Diğer suçlarda şikâyetçinin, devlet başkanının veya hâkimin affetme yetkisi varken hadd cezası gerektiren suçlarda affetme ya da şikâyet etme zorunluluğu söz konu değildir. İçki içmek, Kuran'da yasaklanmış olduğu hâlde işlenen suç için konulmuş bir ceza yoktur. İçki içme cezası hadd-i şürb ya da hadd-i sekr olarak adlandırılmaktadır. Bu suçun cezası daha sonra icma ile kabul edilmiş ve özgür insanlar için seksen, köleler için kırk değnek olarak belirlenmiştir. Cezanın uygulanması ya da uygulanmaması için çeşitli şartların oluşması gerekmektedir. Suçun sabit olduğunun tanıklar tarafından ifade edilmesi, kişinin kendi rızasıyla içmesi ve kişinin Müslüman olması bu şartlardan bazılarıdır (Akbulut, 2003: 167-181).

Görüldüğ̈̈ gibi içki, Müslümanlara haram kılınmış ve Osmanlı hukukunda içki içmenin karşılığı olarak bazı cezalar belirlenmiştir. Fıkralarda da fikra kahramanlarının sıklıkla içki içerken yakalandıkları görülmektedir. Fakat çoğu kez yakalanan kişiler bir yolunu bulup cezadan kurtulmaktadır. Örneğin Bekri Mustafa:

“- İçkinin yasak olduğunu bilmiyor musunuz?

Bekri Mustafa bir kadeh daha yuvarlayarak cevap verir:

- Biz yasağı bildiğimiz için, şarabı imha ediyoruz." (Cimcoz, 2000: 211).

Bekri Mustafa, zeki ve hazırcevap bir insan olduğundan ötürü en sıkıntılı durumlara bile anında çözümler üretebilmektedir. Dönemin padişahı olan 
IV. Murad'ın içki yasağına bakışı ve bu konuda ne kadar katı olduğu bilinmektedir. Bekri Mustafa ise yukarıdaki fikrada bizzat padişaha yakalanmasına rağmen söz oyunları yaparak konunun yönünü değiştirmektedir. Yasaklanmış olan içkiyi, içerek imha ettiğini ifade etmektedir. Burada ironik bir durum söz konusudur. Padişahın yasağını bilen Bekri, bir yandan yasağa uyduğunu göstermeye çalışmakta öte yandan da kendi arzularını yerine getirerek içki içmektedir. Tüm bunları yaparken de nüktedanlığına başvurarak ironik bir üslup geliştirmektedir.

Bekri Mustafa'nın içki yasağıyla ilgili karşı karşıya geldiği, yakalandığı tek kişi Sultan IV. Murad değildir. İçki içerken yeniçeri ağalarına yakalandığı fikralar da mevcuttur:

"Bekri Mustafa, nüdema-yi şehriyari sirasina geçmezden evvel bir akşam sarhoş olarak tutulup karakola götürülmüşs. O sıralarda işret etmek şiddetli memnu olup sarhoş olanlara yirmişer değnek darp edilmek adet imiş. Ertesi günü sabah olunca Bekri Mustafa' yl sarhoş olarak derdest edilen bir hayli eşhas ile yeniçeri ağasının huzuruna çıkarmışlar. Ağa birer birer sormaya başlamıș:

- Sen kimsin?

- Efendim ben yeniçeriyim.

- Ben de yeniçeri ă̆asıyım dövün keratayı. Diğer birine geçmiş:

- Sen nesin?

- Bendeniz kalyoncuyum.

- Ben de kaptan paşayım dövün keratayı. Diğer birine:

- Sen nesin?

- Bendeniz sipahiyim.

- Ben de sipahi zabitiyim dövün keratayl. Diğer birine:

- Sen nesin?

- Bendeniz çulhacıyım.

- Ben de esnaf kâhyasıyım dövün keratayı. diyerek cümlesini dövdürdügünü gören Bekri Mustafa stra kendisine geldiginde A $\breve{g} a$ :

- Sen kimsin? diye sorunca:

- Bendeniz Balata Yahudi Havrası hademesiyim. cevabını vermiş ve ağa bundaki nükteyi anlayıp kahkaha ile gülerek dayaktan af ve ttlak etmiştir." (Emeksiz, 2010: 162-163).

Yukarıda Bekri Mustafa'nın nükteli sözler söyleyerek kendisine verilecek cezadan kurtulduğu görülmektedir. F1krada Osmanlı Devleti’nin 17. yüzyıldaki siyasi, adli ve iktisadi düzenine de değinilmiştir. Yeniçeri ağası kendisine getirilen sarhoşları cezalandırırken bu kişilerin mesleklerini sormuş ve verilen her bir cevaba bir kıdem daha ekleyerek kendisini cezayı vermeye muktedir göstermiştir. Bunu yaparken karşısındakileri aşağılamaya çalışmıştır. Kara kuvveti demek olan yeniçerinin üstünde yeniçeri ağası, deniz kuvveti 
demek olan kalyoncuların başında kaptan paşa, atlı asker demek olan sipahinin başında sipahi zabiti, bez oymacısı demek olan çulhacının başında ahilik teşkilatı yetkilisi olarak esnaf kâhyası vardır. Yeniçeri ağası kendini bu kişilerin amiri olarak göstermiştir. Buna rağmen Bekri Mustafa'nın verdiği cevaba bu şekilde yanıt verememiştir. Çünkü Bekri Mustafa'nın söylediği işe amir olabilmek için ya talmud ya da hahambaşı olması gerekir. Yeniçeri ağası Müslüman olduğu için, kendini gayrimüslim bir din adamı yerine koymak istememiştir. Bekri Mustafa'nın bunu bilerek yaptığını anlamış ve bu duruma gülerek Bekri Mustafa'yı affetmiştir. Öbür yandan fikranın başında bahsedildiği şekliyle, Osmanlıda içki içmenin cezasının yirmi değnek olduğu anlaşılmaktadır. Hadd-i Şirb adı verilen bu ceza, kaynağını İslam hukukundan almaktadir.

Bekri Mustafa'nın içki içerken yeniçeri ağasına yakalanmasını konu alan bir başka fikra örneği de şu şekildedir:

"Yeniçeri ăgalarından Kara Hasanzade, Bekri Mustafa'ya ait şu hatırasını nakleder:

- Bir gün Kumkapı'da bir meyhane bastım. İçindekilerin bazlları tutuldu, bir kısmı da kaçtı. Maiyetimdeki yeniçeriler köşe bucak araştırmalar yaparlarken bir de baktım ki, meyhanenin damındaki bacada Bekri Mustafa'nın başı görünüyor. Ben de at üzerinde olduğum için Bekri'nin bu hali gözümden kaçmamıştı. Bekri Mustafa, kendini gördüğümü anlayınca parmağını dudaklarına götürdü ve bana sus, sesini çıkarma gibisinden işaretler yapmaya başladı. Böyle bir araştırmayı tasarlayan ben olduğumu bildiği hâlde hiç aldırmadan gayet sakin bir tavırla bana bu işareti yapması pek hoşuma gitti. Bu zarif arzı dehalet karşısında sükût ettim, hayvanı sürüp oradan uzaklaştım." (Erksan, 1947: 8).

Yukarıdaki fikranın tarihî gerçekliğinin olması, fikrayı önemli kılmaktadır. Bekri Mustafa'nın ironik ve mizahi tavrına, fikrayı nakleden Kara Hasanzade bizzat şahit olmuştur.

İçki yasağını anlatan bir başka fikrada ise Bekri Mustafa mizahi yönünü kadiya göstermektedir:

"Bir gün Bekri Mustafa'yı sarhoş hâlde yakalayıp kadı efendinin huzuruna götürürler. Kadı hiddetle der ki: mışsın?

- Ayıp değil mi sana. Bu yaşa, şu boya gelmişsin hâlâ şu mundarı bırakama-

- İyi amma efendi hazretleri benim o mundarı temiz bir yere gönderdiğim yok $k i !$

- Yalan söylüyorsun. Bak üstüne başına dökmüşsün.

- Hakkınız var kadı efendi. Kopası ellerim titriyor, yoksa bir katresini bile ziyan etmek istemem.

- Peki, haram olduğunu da bilmiyor musun? sanki?

- Iyi amma efendi hazretleri, sizin arkanızdaki ibrişim kaftan helal midir 
- Tabii helaldir, çünkü içine pamuk katılmıştır.

- Bize de meyhaneciler safi şarap vermezler, yarl yarlya su katarlar da öyle verirler. Şu hâlde şarap da helaldir." (Erksan, 1947: 5).

F1krada, Osmanlının kuruluşundan çöküşüne kadar adaleti tesis etmekle görevli olan kadılık makamının o dönemki hâline değinilmiştir. Sarhoş yakalanıp kadının huzuruna çıkarılan Bekri Mustafa’nın, kendisini azarlayan ve cezalandırmak isteyen kadıya eleştirel ve bir o kadar da mizahi cevaplar verdiği görülmektedir. Kadı, içkinin haram olduğundan bahsetmektedir. Bekri Mustafa ise kadının yaşantısının haram olduğunu belirtmektedir; çünkü kadı ibrişim kaftan giymiştir. İbrişim kaftan, Osmanlı döneminde padişahın, üst düzey devlet adamlarının giydiği, ipekten yapılan bir çeşit giysidir. İpek ise Hz. Muhammed'in hadisiyle Müslüman erkeğe haram kłılınmıştır. Bekri Mustafa, kendisini azarlayan kadıya bu şekilde bir cevap vererek içinde bulunduğu olumsuz durumdan kurtulmayı amaçlamaktadır. Aynı zamanda bu fikra, 17. yüzyıl Osmanlısının bozulmakta olan adlî yapısının da bir resmidir. İşi İslam hukuku çerçevesinde adaleti temin ve tesis etmek olan kadı, lüks bir hayat içinde yaşamaktadır ve bu durum Bekri Mustafa tarafından eleştirilmektedir. $\mathrm{Bu}$ konuya bağlı olarak Şimşek: "Aldıkları karar ve davranışlarla doğruluk ilkesinden ayrılmamaları gereken kadıların yanı sıra, zaman zaman çeşitli sebeplere bağlı olarak olması gerekenin tersine karar alanlar da çıkmıştır. Hiç şüphesiz böylesine önemli bir görevi üstlenen kadılara yanlış ve hatalı kararlar yakıştırılmamış, onların küçücük hatalarl, sosyal hayatta olduğu gibi edebiyatımızda da eleştiri konusu olmuştur." (Şimşek, 2018: 28) demektedir. Bekri Mustafa, zeki ve hazırcevap olduğu gibi, aynı zamanda açık sözlü biridir. Onun sarhoşluğu kendinedir, sadece kendine zarar verir. Öbür yandan dürüst bir kişidir. Haksızlıklara müdahale eder. Bu fikradaki eleştiri, bir sarhoş gözüyle yapılmaktadır. İçki yasağına karşı olanların, bu durumu büyük günah görenlerin, aslında kendilerinin farkında olarak ya da olmadan başka büyük günahların içerisinde olduğunu göstermeye çalışmaktadır. Bekri Mustafa yukarıdaki fikraların çoğunda içki yasağıyla mücadele etmiş, yasağı her seferinde delip çok kez yakalanmış; fakat her seferinde kurtulmayı başarmıştır. Bu sebeple çoğu zaman tebdili kıyafet dolaşan Sultan IV. Murad ile karşı karşıya gelmiştir.

\section{Sonuç ve Değerlendirme}

16. yüzyıldan itibaren Osmanlı idaresinin alkollü içki tüketimine yönelik hassasiyeti giderek artmıştır. Bunda İslamiyet'in içkiye bakışı ve toplumsal düzenin bozulmasına dönük endişeler ön plandadır. Bu doğrultuda Kanuni Sultan Süleyman ve Sultan IV. Murad Dönemlerinde katı yasaklar getirilmiş; fakat içkinin kaçak yollarla üretimi ve gizlice tüketimi sürmüştür. İçkiye yö- 
nelik tepki, özellikle siyasi ve sosyal krizlerin yaşandığı dönemlerde daha belirgin hâle gelmiştir. Sultan III. Selim Dönemi'nde, bir yandan savaşlar devam ederken öbür yandan İstanbul'da içki tüketiminin ciddi düzeyde artması neticesinde içki tüketimi men edilmiş; fakat bu sefer yasağın sınırları genişleterek gayrimüslimler de yasağa dâhil etmiştir. İçkinin yasaklanmasında şüphesiz ki konunun siyasi işlevi de göz ardı edilmemiştir. İçki içenlerin, içkinin verdiği ruh hâliyle Osmanlı idaresine eleştirilerde bulunması, bu yasak kararının alınmasinda etkili olan sebeplerden biridir.

F1kralarda, yaşanan hayat yansıtılmaktadır. Dolayısıyla beşeri konulara sıkça yer verilmektedir. Bektaşi fikra tipine ve Bekri Mustafa'ya bağlı olarak anlatılan fikralarda da dönemin sosyal yaşantısına etki eden siyasi gelişmeleri görmek mümkündür. Osmanlı Devleti'nin kuruluşundan beri var olan; fakat duraklama döneminden itibaren yoğun olarak uygulanan içki yasağı bu fikralarda sıklıkla eleştirilmektedir. İslami inanışta da hoş karşılanmayan içki kullanımı, kimi padişahlar tarafından ciddi sorun olarak görülüp üzerinde durulmuştur. Burada dikkat çeken önemli bir nokta yasağı koyan ve uygulanmasından sorumlu olan padişahların, fikralarda tıpkı Bekri Mustafa ya da Bektaşi gibi hazırcevap/nüktedan olmaları ve çoğunlukla duruma karşı müsamahakâr davranmalarıdır. Osmanlı Devleti'nin duraklama ve gerileme dönemlerinin işlendiği bu fikralarda şikâyet edilen durum sadece içki yasağı değil, aynı zamanda devletin içinde bulunduğu kaotik ortamdır. Fıkraların çoğunda bu yasakların her firsatta delindiğinin gösterilmesiyle, aslında kaybolan Osmanlı otoritesine vurgu yapılmaktadır.

\section{KAYNAKÇA}

Akbulut, İlhan (2003); "İslam Hukukunda Suçlar ve Cezalar", Ankara Üniversitesi Hukuk Fakültesi Dergisi, S. 52, s.167-181, Ankara. tanbul.

Boratav, Pertev Naili (2000); 100 Soruda Türk Halk Edebiyatı, Gerçek Yayınevi, İs-

Cimcoz, Sinâ (2000); Adamın Biri Bir Gün... Bektaşi Fıkraları, Bekri Mustafa Fıkraları, Geçit Kitabevi, İstanbul.

Ekinci, Ekrem Buğra (2014); Ama Hangi Osmanl, Timaş Yayınları, İstanbul. İstanbul.

Emeksiz, Abdulkadir (2010); Bir İstanbul Kahramanı Bekri Mustafa, Mühür Kitaplığı,

Ferris, William (1997); "Halk Şarkılart ve Kültür: Charles Seeger ve Alan Lomax". (çev. F. G. Mirzaoğlu), Millî Folklor, S. 34, s. 87-93.

İpekten, Haluk (1996); Edebî Muhitler, MEB Basımevi, Ankara.

Kaflı, Kadircan (1943); Osmanlı Devrinden Tarihî Fıkralar, Ahmet Sait Matbaası, İstanbul. Konya.

Kaşgarlı Mahmud (2012); Divânü Lügati't-Türk (çev. F. Bozkurt), Eğitim Yayınevi,

Orhonlu, Cengiz (1966); “Osmanlı Türkleri Devrinde İstanbul'da Kaylkçıllk”, İstanbul Üniversitesi Edebiyat Fakültesi Tarih Dergisi, S. 21, s. 109-134, İstanbul. 


\section{Prof. Dr. ESMA ŞİMŞEK / Dr. ÖMER FARUK ELALTUNTAŞ}

Pakalın, Mehmet Zeki (1993); Osmanlı Tarih Deyimleri ve Terimleri Sözlüğü, MEB Yayınları, Ankara. Ankara.

Ricaut, Paul (2004); Türklerin Siyasi Düsturları. (çev. M. F. Topaloğlu), Elips Kitap,

Seratlı, Tahir Galip (2004); Mizahımızın Üç Ustası Nasreddin Hoca İncili Çavuş Bekri Mustafa, Selis Kitabevi, İstanbul.

Şenocak, Ebru (2017); İronik Yaşamda Sonsuza Yürüyen Kahraman Nasreddin Hoca, Akçağ Yayınları, Ankara.

Şimşek, Esma (2015);“Türk Halk Edebiyatı Anlatı Türleri İ̧̧erisinde Fıkraların Yeri”, Akra Kültür Sanat ve Edebiyat, S. 6, s. 195-234, İstanbul.

Şimșek, Esma (2018); "Kadı Imgesinin Edebiyatımıza Yansımaları ve Sıdkî Baba'nın 'Kadı' Destanı Örneği”, Akra Kültür Sanat ve Edebiyat, S. 14, s. 27-40, İstanbul.

Yıldırım, Dursun (1999); Türk Edebiyatında Bektaşi Fıkraları, Akçağ Yayınları, Ankara.

Yusuf Has Hacib (2003); Kutadgu Bilig. (haz. R. R. Arat), TTK Yayınları, Ankara. 